\title{
Raillietiella mottae (Pentastomida: Raillietiellidae) parasitizing four species of Gekkota lizards (Gekkonidae and Phyllodactylidae) in the Brazilian Caatinga
}

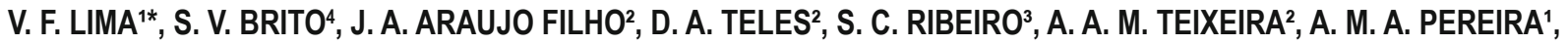 \\ W. O. ALMEIDA ${ }^{1}$
}

\begin{abstract}
1Programa de Pós-Graduação em Bioprospecção Molecular, Departamento de Química Biológica, Universidade Regional do Cariri - URCA, Rua Cel. Antônio Luiz, 1161, Campus do Pimenta, 63105-000, Crato, Ceará, Brazil, E-mail: vandeberglima@hotmail.com; ${ }^{2}$ Programa de Pós-Graduação em Ciências Biológicas (Zoologia), Departamento de Sistemática e Ecologia - DSE, Centro de Ciências Exatas e da Natureza - CCEN, Universidade Federal da Paraíba - UFPB, Cidade Universitária, Campus I, CEP 58059-900, João Pessoa, Paraiba, Brazil; ${ }^{3}$ nstituto de Formação de Educadores - IFE, Universidade Federal do Cariri - UFCA, Campus Brejo Santo, CEP 63260-000, Brejo Santo, Ceará, Brazil; ${ }^{4}$ Centro de Ciências Agrárias e Ambientais, Universidade Federal do Maranhão - UFMA, Boa Vista, CEP 65500-000, Chapadinha, Maranhão, Brazil
\end{abstract}

\section{Article info}

Received July 4, 2017 Accepted January 26, 2018

\begin{abstract}
Summary
We tested the role of sex, size, and mass of the lizards Phyllopezus pollicaris, Gymnodactylus geckoides, Hemidactylus agrius, Lygodactylus klugei, and Hemidactylus brasilianus on the rates of pentastomid infection in the Brazilian Caatinga. We collected 355 individuals of these five species, of which four (prevalence of infection: P. pollicaris $15.9 \%$, G. geckoides $1.4 \%, H$. agrius $28.57 \%$, and $H$. brasilianus $4.16 \%$ ) were infected by Raillietiella mottae. Parasite abundance was influenced by host body size and mass only in P. pollicaris. Host sex did not influence the abundance of parasites in any species. Hemidactylus agrius, G. geckoides, and $H$. brasilianus are three new host records for pentastomids.
\end{abstract}

Keywords: Geckos; Pulmonary parasite; Semi-arid; South America

\section{Introduction}

Pentastomids are endoparasites of the vertebrate respiratory system, whose definitive or intermediate hosts are usually reptiles. There are five pentastomid species of the genus Raillietiella that parasitize lizards in the Neotropics: $R$. cartagenensis Ali Riley \& Self, 1985, $R$. freitasi (Motta \& Gomes, 1968), R. furcocerca (Diesing, 1863), $R$. frenata Ali, Riley \& Self, 1981, and R. mottae Almeida, Freire \& Lopes, 2008.

Previous studies found pentastomids infecting insectivorous lizards in Brazil. For example, one study found Mabuya agilis (Raddi, 1823) infected by Raillietiella sp. (Vrcibradic et al., 2002). Another study in a restinga (Almeida et al., 2009a) found Cnemidophorus abaetensis Dias, Rocha \& Vrcibradic, 2002 and C. ocellifer (Spix, 1824) parasitized by Raillietiella aff. furcocerca (Almeida et al., 2009a) and Micrablepharus maximiliani (Reinhardt
\& Luetken, 1862) parasitized by R. mottae (Almeida et al., 2009a). Also, Anjos et al. (2007) and Almeida et al. (2008c) found R. mottae and $R$. renata, Sousa et al. (2014) recorded only $R$. mottae parasitizing Hemidactylus mabouia (Moreau de Jonnès, 1818) in houses, $R$. frenata in the north east coast of Brazil (Bezerra et al., 2016), while Trachylepis atlantica (Schmidt, 1945) was infected by $R$. freitasi in the Archipelago of Fernando de Noronha, Pernambuco (Brito et al., 2012). In the Caatinga, $R$. mottae was recorded infecting Tropidurus hispidus (Spix, 1825) (Almeida et al., 2008a, 2008b, 2009b; Brito et al., 2014b; Araujo Filho et al., 2016), T. semitaeniatus (Spix, 1825) (Almeida et al., 2008b, 2009b, Brito et al., 2014b), Phyllopezus periosus Rodrigues, 1986 (Almeida et al., 2008b; Brito et al., 2014b), P. pollicaris (Spix, 1825) (Almeida et al., 2008b; Sousa et al., 2010, 2014; Brito et al., 2014b) and M. arajara Rebouças-Spieker, 1981 (Ribeiro et al., 2012).

Regarding abundance of pentastomids in Brazil, previous studies,

\footnotetext{
* - corresponding author
} 
found less than $14 \%$ prevalence for pentastomids with at least 15 lizards collected from the same species. For example, C. abaetensis ( $n=33$, prev. $=6 \%$, Dias et al., 2005), C. ocellifer $(n=40$, Prev $=2.5 \%), M$. agilis $(\mathrm{n}=28$, Prev $=3.6 \%$, Vrcibradic et al., 2002), T. hispidus ( $\mathrm{n}=18$, Prev = 11.1\%, Almeida et al., 2008a; $n=288$, Prev. $=1 \%$, Brito et al., 2014b; $n=411$, Prev. $=0.66 \%$ ); T. semitaeniatus ( $n=15$, Prev $=13.3 \%$, Almeida et al., 2008b; $n$ $=120$, Prev $=0.51 \%$, Brito et al., 2014b); M. maximiliani $(\mathrm{N}=75$, Prev $=4 \%$, Almeida et al., 2009a), and M. arajara ( $n=125$, Prev $=$ $1.6 \%$, Ribeiro et al., 2012). Only three studies with similar sample size (15 geckos) found a higher prevalence: $H$. mabouia $(n=37$, Prev $=45.9 \%$, Anjos et al., 2007; $n=30$, Prev $=20 \%$, Almeida et al., 2008c) and P. pollicaris ( $\mathrm{n}=22$, Prev $=18.18 \%$, Sousa et al., 2010).

Here we tested the role of host body size, mass and sex on the abundance of pentastomids in the insectivorous geckos $P$. pollicaris and Gymnodactylus geckoides (Spix 1825) (Phyllodactylidae), H. agrius Vanzolini, 1978, Lygodactylus klugei (Smith, Martin \& Swain, 1977), and H. brasilianus (Amaral, 1935) (Gekkonidae) in a Caatinga area. These species were chosen because they have been reported to have higher prevalence in the literature.

\section{Material and Methods}

Lizard sampling and parasite identification

We sampled lizards at the Aiuaba Ecological Station (ESEC Aiua-

a)

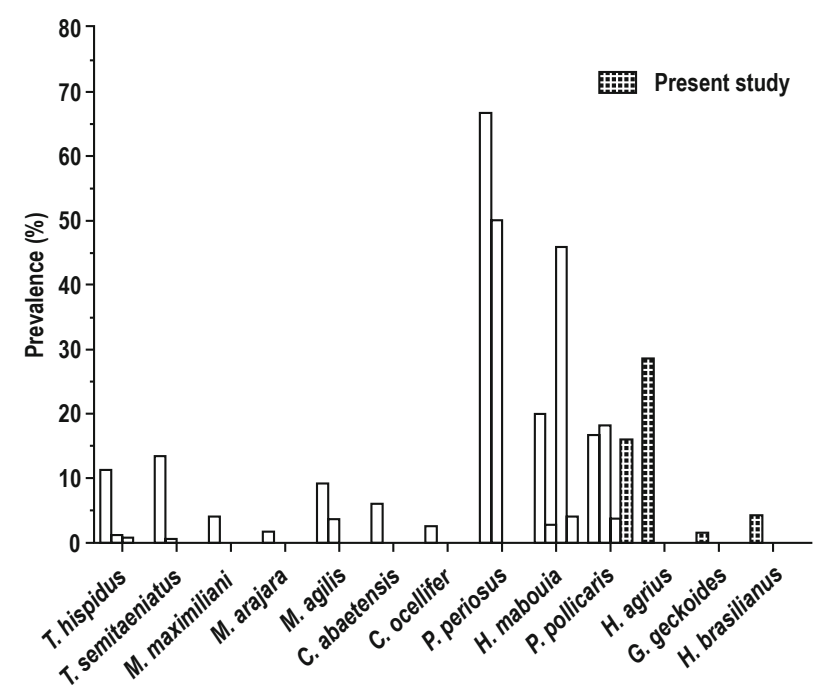

ba), municipality of Aiuaba, state of Ceará, northeastern Brazil $\left(6^{\circ}\right.$ $36^{\prime} 27^{\prime \prime} \mathrm{S} ; 40^{\circ} 08^{\prime} 00.9^{\prime \prime} \mathrm{W}$ ), which is within the Caatinga. The vegetation is composed of hypoxerophilic plants, shrubs, thorny trees, and open formations (Andrade-Lima, 1981). The climate is warm semi-arid tropical, with an average annual rainfall of $562.4 \mathrm{~mm}$; the average temperature varies from $24^{\circ} \mathrm{C}$ to $26^{\circ} \mathrm{C}$, with a short rainy period between February and April (IPECE, 2011).

We collected lizards using visual encounter surveys (McDiarmid, 2012) in September and November 2014 and February and April 2015. We measured Snout-Vent Length (SVL) with a digital caliper (to the nearest $0.01 \mathrm{~mm}$ ), body weight with a digital scale (to the nearest $0.01 \mathrm{~g}$ ). Then, we removed the specimens' respiratory tract under the stereomicroscope to inspect and count the parasites. Sex and sexual maturity were determined by analyzing the gonads. Mature males were those individuals with developed testes and epididymas with convolutions, and mature females were those with vitellogenic follicles in ovaries or oviducts. Lizards were killed with a lethal dose of lidocaine and fixed with $10 \%$ formaldehyde and stored in $70 \%$ ethanol.

Parasites were lightened in Hoyer medium (Everhart, 1957), mounted on temporary slides, and preserved in $70 \%$ ethanol. Identification was conducted under microscope coupled with gridded ocular based on the size of mating hooks and spicules of males (Riley et al., 1986; Almeida et al., 2008a). Parasites will be deposited in the Parasitological collection of the Regional University of Cariri - URCA.

b)

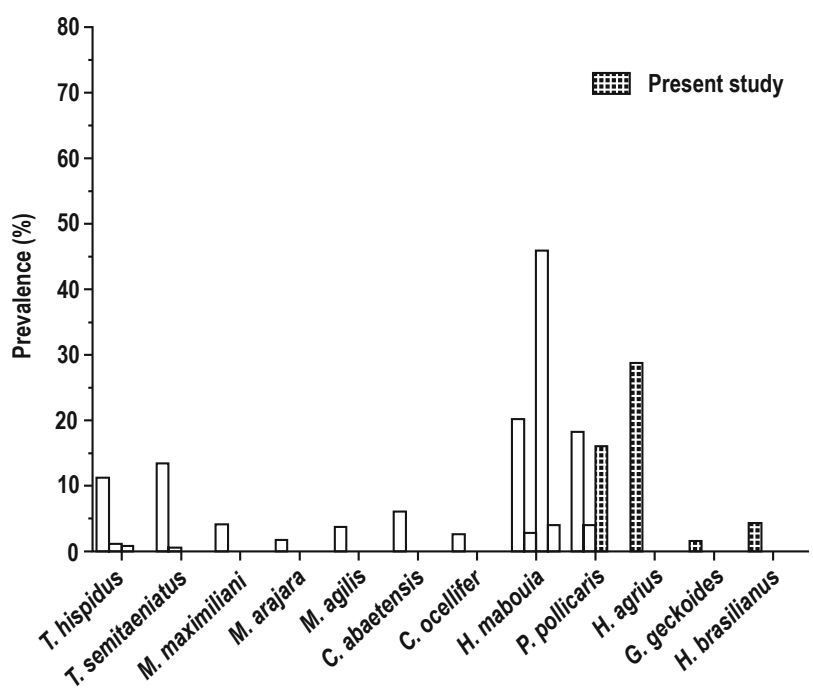

Fig. 1. Pentastomids as parasites of insectivorous lizards in Brazil. Data from the literature and the present study. a) All infection records for pentastomids in Brazil including this study, b) includes only studies that sampled more than 15 individuals of the same lizard species. References with number of hosts in parenthesis: Tropidurus hispidus ( $n=18$, Almeida et al., 2008a; $n=288$, Brito et al., 2014b; $n=411$, Araujo-Filho et al., 2016), T. semitaeniatus ( $n=15$, Almeida et al., 2008b; $n=120$, Brito et al., 2014b), Micrablepharus maximiliani $(n=75$, Almeida et al., 2009a), Mabuya arajara $(n=125$, Ribeiro et al., 2012), M. agilis $(n=11, n=28$, Vrcibradic et al., 2002), Cnemidophorus abaetensis ( $n=33$, Dias et al., 2005), C. ocellifer ( $n=40$, Dias et al., 2005), Phyllopezus periosus ( $n=6$, Almeida et al., 2008b; $\mathrm{n}=6$, Brito et al., 2014b), Hemidactylus mabouia ( $\mathrm{n}=37$, Anjos et al., 2007; $\mathrm{n}=30$, Almeida et al., 2008c; $\mathrm{n}=76$, Sousa et al., 2014; $\mathrm{n}=277$, Bezerra et al., 2016), P. pollicaris ( $n=6$, Almeida et al., 2008b; $n=22$, Sousa et al., 2010; $n=94$, Brito et al., 2014b; $n=132$, this study) H. agrius ( $n=63$, this study), Gymnodactylus geckoides ( $n=71$, this study) and H.brasilianus ( $n=24$, this study). 


\section{Statistical analyses}

We calculated the prevalence (the number of hosts infected by one or more parasites divided by total hosts number), abundance (the number of parasites of a given host whether or not it is infected), range (the number of parasites in a given host species, with a smallest number is given the number one, and other numbers represent the largest number of parasites found in an individual of the host species) and mean intensity of infection (the total number of parasites species found in a sample divided by the number of hosts infected with that parasite) for each lizard species following Bush et al. (1997). First, we tested whether there is a relationship between pentastomids abundance (response variable, log-transformed and using a Poisson response distribution) and SVL, sex, species and interaction between sex and species of lizards. Second, we tested whether there is a relationship between infection (presence/absence and using a binomial response distribution) and the explanatory variables, mass, sex, species and interaction between sex and species of lizards, the selected statistical test Generalized Linear Model (GLM) is efficient to avoid the confounding effect of host size (Poulin, 1997). We only used host species with more than ten individuals infected (at least five males and five females) in the analyses. Only $P$. pollicaris and $H$. agrius met this criterium, because $G$. geckoides and $H$. brasilianus presented only one lizard infected by pentastomids. All analyzes were performed using the Software $R$, package "R commander" (R core team, 2008) (Wilson \& Grenfell, 1997).

\section{Ethical Approval and/or Informed Consent}

The research related to animals use has been complied with all the relevant national regulations and institutional policies for the care and use of animals.

\section{Results}

We collected 355 individuals from five lizard species. Of these, three species belonged to the family Gekkonidae $H$. agrius: 28 males $(\mathrm{SVL}=47.07 \pm 3.83 \mathrm{~mm})$ and 35 females $(\mathrm{SVL}=47.82 \pm$ $3.78 \mathrm{~mm}$ ); L. klugei: 25 males (SVL $=27.52 \pm 2.58 \mathrm{~mm}$ ) and 40 females (SVL $=28.02 \pm 2.41 \mathrm{~mm}$ ); and $H$. brasilianus: 11 males $(S V L=45 \pm 5.93 \mathrm{~mm})$ and 13 females $(S V L=43.61 \pm 5.70 \mathrm{~mm})$ And another two species belonged to the family Phyllodactylidae P. pollicaris: 57 males $(\mathrm{SVL}=64.22 \pm 8.40 \mathrm{~mm})$ and 75 females $(\mathrm{SVL}=62.58 \pm 11.93 \mathrm{~mm}) ; \mathrm{G}$. geckoides: 30 males $(\mathrm{SVL}=37.76$ $\pm 3.70 \mathrm{~mm}$ ) and 41 females (SVL $=37.53 \pm 4.12 \mathrm{~mm}$ ) (Fig. 1). The only parasite species found in four of the five lizard species was Raillietiella mottae (Table 1).

Body size and mass were significant for the abundance of pentastomids only for $P$. pollicaris, only when related by host sex. However, the SVL and mass only become significant in the part of the response variable (infected or uninfected host), regardless of the intensity of the infection (number of parasites per infected lizard). Thus, the SVL and mass determine whether or not the lizard will be infected, but not how many parasites it will harbor. Both sex and species were significant in both parts of the model, that is, these factors influence the infection and the amount of parasites (Table 2). We recorded three new hosts for $R$. mottae: $H$. agrius, $H$. brasilianus, and G. geckoides. There was no damage to the lung tissue of infected lizards.

\section{Discussion}

All lizard species found are of nocturnal activity and have a sit-andwait foraging mode (Vanzolini, 1968). However, they differ in the strata used to forage. For example, Hemidactylus agrius and $P$. pollicaris are common in rocky outcrops, while Hemidactylus brasilianus and L. klugei are tree dwellers, and G. geckoides forages in the leaf litter (Vitt et al., 1995; Colli et al. 2003; Rocha et al., 2005; Mesquita et al., 2006; Sousa et al., 2010; Recorder et al., 2012; Albuquerque et al., 2013; Passos et al., 2014). The similar nocturnal activity of the species may render similar insect prey and allow the infection by $R$. mottae, which seems to be a generalist parasite,

Table 1. Total infection rates for each lizard species discriminated by sex in the Ecological Station of Aiuaba, Ceará, Brazil.

\begin{tabular}{|c|c|c|c|c|c|c|}
\hline \multirow{4}{*}{ Species } & \multicolumn{6}{|c|}{ Raillietiella mottae } \\
\hline & \multicolumn{6}{|c|}{ Prevalence (\%) Intensity (range) } \\
\hline & & & \multicolumn{4}{|c|}{ Sex } \\
\hline & \multicolumn{2}{|c|}{ Total } & \multicolumn{2}{|c|}{ Male } & \multicolumn{2}{|c|}{ Female } \\
\hline Hemidactylus agrius & $28.57 \%$ & $1.66(1-5)$ & $39.28 \%$ & $1.27(1-2)$ & $20 \%$ & $2.28(1-5)$ \\
\hline Hemidactylus brasilianus & $4.16 \%$ & $1(1)$ & 0 & 0 & $7.69 \%$ & $1(1)$ \\
\hline \multicolumn{7}{|l|}{ Phyllodactylidae } \\
\hline Phyllopezus pollicaris & $15.9 \%$ & $1.9(1-5)$ & $87.7 \%$ & $2(1-5)$ & $21.33 \%$ & $1.87(1-3)$ \\
\hline Gymnodactylus geckoides & $1.4 \%$ & $5(5)$ & $0 \%$ & 0 & $2.43 \%$ & $5(5)$ \\
\hline
\end{tabular}


Table 2. Generalized Linear Model (GLM) in Poisson distribution on the variation of the pentastomids abundance related to the host specie (Phyllopezus pollicaris), sex, mass, Snout-Vent Length (SVL) and interaction SVL, mass with sex $\times$ host species. Values of $P$ presented in italics are statistically significant.

\begin{tabular}{lcccc}
\hline & Estimate & Std. Error & $\mathrm{z}$ value & $\mathrm{P}$ \\
\cline { 2 - 5 } Abundance $\sim$ SVL & -0.062 & 0.035 & -1.778 & 0.075 \\
Abundance $\sim$ Sex & -1.136 & 0.496 & -2.292 & 0.022 \\
Abundance $\sim$ SVL * Sex & 1.512 & 0.684 & 2.212 & 0.027 \\
& & & & \\
Abundance $\sim$ Mass & 0.344 & 0.072 & 4.790 & 0.167 \\
Abundance $\sim$ Sex & 0.117 & 0.366 & 0.320 & 0.749 \\
Abundance $\sim$ Mass * Sex M & -1.080 & 0.517 & -2.088 & 0.037 \\
\hline
\end{tabular}

infecting several lizard species (Dias et al., 2005; Vrcibradic et al., 2002; Anjos et al., 2007; Almeida et al., 2008a, 2008b, 2008c, 2009a; Sousa et al., 2010, 2014; Ribeiro et al., 2012; Brito et al., 2014b; Araujo Filho et al., 2016).

However, there is no records of insects as intermediate hosts for $R$. mottae, even though Lavoipierre \& Lavoipierre (1966) found Periplaneta americana as intermediate host of $R$. hemidactyli in Singapore. Almeida et al. (2008b) suggested that ants and termites could be intermediate hosts, because these insects are commonly found in lizard diets (Vitt et al., 1995, Colli et al., 2003, Rocha et al., 2005; Mesquita et al., 2006; Sousa et al., 2010; Recoder et al., 2012; Albuquerque et al. 2013; Passos et al., 2014) which could possibly contribute to infections.

The infected species (H. agrius, H. brasilianus, and G. geckoides) represent three new host records for $R$. mottae. We did not find lung lesions, probably because the maximum load of parasites in a single lizard was five. Pulmonary lesions in geckos are more frequent when they are infected by more than nine pentastomids (Riley et al., 1991).

The prevalence of $R$. mottae in Brazilian lizards varies according to the species, but it seems that only geckonids have a prevalence above 14 \% (Anjos et al., 2007; Almeida et al., 2008c; Sousa et al., 2010; this study). Pentastomids may have a long co-evolutionary history with geckonids. This would also explain the small prevalence of $R$. mottae in other lizard lineages, even with large sample sizes (Dias et al., 2005; Vrcibradic et al., 2002; Almeida et al., 2008b; 2009a, Ribeiro et al., 2012, Brito et al, 2014b, Araujo Filho et al., 2016). These lizards would be occasional hosts due to opportunistic infections. Future studies are needed to confirm these hypotheses.

Host size and mass influenced the abundance of pentastomids only in $P$. pollicaris, mainly in males (only when related to host sex), but not in the amount of pentastomids per lizards (range). This relationship is identified here for the first time and is probably due to larger individuals having larger home ranges, having a more diverse diet of invertebrates, using a wider range of microhabitat, and being active longer. Thus this ratio of higher SVL and mass, represent higher niche and consequently greater abundance of pentastomides can be intensified in males of the host species in question. In addition the range might be influenced other factors not tested in the present study, possibly humidity, seasonality, temperature, among others. However, the same does not apply to larger lizards such as Salvator merianae and Ameivula ocellifera (Brito et al., 2014a; Ramalho et al., 2009; Teixeira et al., 2017). The present study adds three new host records for $R$. mottae. Also, we found a positive relation between host size and mass in infection by pentastomids in lizards of the families Phyllodactylidae and Gekkonidae in the Caatinga. However, further studies are needed to better understand the ecological and co-evolutionary relationships between lizards and pentastomids in this biome.

\section{Conflict of Interest}

Authors state no conflict of interest.

\section{Acknowledgements}

We thank the support of the Coordenação de Aperfeiçoamento de Pessoal de Nivel Superior (CAPES) for the scholarship of V.F. Lima, A.A.M. Teixeira, A.M.A. Pereira; and the Conselho Nacional de Desenvolvimento Científico e Tecnológico - CNPq (PQ302429/2015-8) for the research fellowship given to W.O.Almeida and scholarship of J. A. Araujo-Filho, D. A. Teles. Diogo B. Provete reviewed the English language. The study was approved by the Instituto Chico Mendes de Conservação da Biodiversidade with the permit to collect the animals (process 43753-1).

\section{References}

Albuquerque, N.R.D., Costa-Urquiza, A.D.S., Soares, M.P., Alves, L.S., URQUIZA, M.V.S. (2013): Diet of two sit-and-wait lizards, Phyllopezus pollicaris (Spix, 1825) (Phyllodactylidae) and Hemidactylus mabouia (Moreau de Jonnès, 1818) (Gekkonidae) in a perianthropic area of Mato Grosso do Sul, western Brazil. Biota Neotrop., 13(4): 376 - 381. DOI: 10.1590/S1676-06032013000400032

AlmeidA, W.O., FreiRE, E.M.X., Lopes, S.G. (2008a): A new species 
of Pentastomida infecting Tropidurus hispidus (Squamata: Tropiduridae) from caatinga in Northeastern. Braz. J. Biol., 68(1): 631 - 637. DOI: 10.1590/S1519-69842008000100029

Almeida, W.O., Santana, G.G., Vieria, W.L.S., Wanderley, I.C., Freire, E.M.X., Vasconcellos, A. (2008b): Pentastomid, Raillietiella mottae Almeida, Freire \& Lopes, 2008, infecting lizards in an area of caatinga, Northeast. Braz. J. Biol., 68(2): 203 - 207. DOI: 10.1590/S1519-69842008000200028

Almeida, W.O., Santana, G.G., Vieira, W.L.S., Wanderley, I.C. (2008c): Infection rates of pentastomids on lizards in urban habitats from Brazilian Northeast. Braz. J. Biol., 68(4): 885 - 888. DOI: 10.1590/S1519-69842008000400026

Almeida, W.O., Santana, G.G., Vieira, W.L.S., Wanderley, I.C., RIBEIRO, S.C., (2009a): Rates of pulmonary infection by pentastomids in two lizard species from a restinga habitat in northeastern Brazil. Braz. J. Biol., 69(1): 631 - 637. DOl:10.1590/S1519$\overline{69842009000100026}$

Almeida, W.O., Ribeiro, S.C., Santana, G.G., Vieira, W.L.S., Anjos, L.A., SALES, D.L. (2009b): Lung infection rates in two sympatric Tropiduridae lizard species by pentastomids and nematodes in northeastern Brazil. Braz. J. Biol., 69(3): 963 - 967.DOI: 10.1590/ S1519-69842009000400027

AndRAde-LIma D. De (1981): The caatingas dominium. Rev. Bras. Bot., 4: 149 - 163

Anjos, L.A., Almeida, W.O., Vasconcellos, A., Freire, E.M.X., RoCHA, C. F. D. (2007): The alien and native pentastomids fauna of an exotic lizard population from Brazilian Northeast. Parasitol. Res., 101(3): 627 - 628. DOI: 10.1007/s00436-007-0526-7

Araujo Filho, J.A., Brito, S.V., Lima, V.F., Pereira, A.M.A., MesQUitA, D.O., Albuquerque, R.L., Almeida, W.O. (2016): Influence of temporal variation and host condition on helminth abundance in the lizard Tropidurus hispidus from north-eastern Brazil. J. Helminthol., 91(3): 312 - 319. DOI: 10.1017/S0022149X16000225

Brito, S.V., Almeida, W.O., Anjos, L.A., Silva, R.J. (2012): New host records of Brazilian pentastomid species. Braz. J. Biol., 72(2): 393 - 396. DOI: 10.1590/S1519-69842012000200022

Brito, S.V., Ferreira, F.S., Ribeiro, S.C., Anjos, L.A., Almeida, W.O., MesquitA, D.O., Vasconcellos, A. (2014a): Spatial-temporal variation of parasites in Cnemidophorus ocellifer (Teiidae) and Tropidurus hispidus and Tropidurus semitaeniatus (Tropiduridae) from Caatinga areas in northeastern Brazil. Parasitol. Res., 113(3): 1163 - 1169. DOI: 10.1007/s00436-014-3754-7

Brito, S.V., Corso, G., Almeida, A.M., Ferreira, F.S., Almeida, W.O., Anjos, L.A., Mesquita, D.O., Vasconcellos, A. (2014b): Phylogeny and micro-habitats utilized by lizards determine the composition of their endoparasites in the semiarid Caatinga of Northeast Brazil. Parasitol. Res., 113(11): 3963 - 3972. DOI: 10.1007/s00436-0144061

Bush, A.O., Lafferty, K.D., Lotz, J.M., Shostak, A.W. (1997): Parasitology meets ecology on its own terms: Margolis et al. revisited. J. Parasitol., 83(4): 575 - 583. DOI: 10.2307/3284227

Colli, G.R., Mesquita, D.O., Rodrigues, P.V., Kitayama, K. (2003):
Ecology of the gecko Gymnodactylus geckoides amarali in a Neotropical savanna. J. Herpetol., 37(4): 694 - 706. DOI: 10.1670/180$02 \mathrm{~A}$

DiAs, E.J.R., VRCIBRAdIC, D., RochA, C.F.D. (2005): Endoparasites infecting two species of Whiptail lizard (Cnemidophorus abaetensis and C. Ocellifer, Teiidae) in a 'Restinga' Habitat of North-Eastern Brazil. Herpetol J., 15(2): 133 - 137

EverHART, B.A. (1957): Notes on the helminths of Pseudemys scripta elegans Wied, 1838 in areas of Texas and Oklahoma. Proc. Oklahoma Acad. Sci., 38: 38 - 43

IPECE (Instituto de Pesquisa e Estratégia Econômica do Ceará) (2011): Perfil Básico Municipal: Aiuaba [Ceará Research Institute on Economic Strategy: Basic profile of municipality: Aiuaba]. Instituto de Pesquisa e Estratégia econômica do Ceará (IPECE). Fortaleza- Ceará. 1 - 18 (In Portuguese)

McDIARMID, R.W. (2012): Reptile biodiversity: standard methods for inventory and monitoring. 1rd edn. 412 pp. University of California Press.

Mesquita, D.O., Colli, G.R., França, F.G., Vitt, L.J. (2006): Ecology of a Cerrado lizard assemblage in the Jalapão region of Brazil. Copeia., 2006(3): 460 - 471. DOI: 10.1643/0045-8511(2006)2006[460:EOACLA]2.0.CO;2

Passos, D.C., Barbosa Galdino, C.A., Bezerra, C.H., Zanchi-Silva, D. (2015): On the natural history of the poorly known Neotropical lizard Hemidactylus agrius (Squamata: Gekkonidae). North. West. J. Zool., 11(1): 133 - 137

PoulIN, R. (1997): Species richness of parasite assemblages: evolution and patterns. Annu. Rev. Ecol. Evol. Syst., 28(1): 341 - 358. DOI: 10.1146/annurev.ecolsys.28.1.341

Ramalho, A.C.O., Da Silva, R.J., Schwartz, H.O., Péres Jr, A.K. (2009): Helminths from an introduced species (Tupinambis merianae), and two endemic species (Trachylepis atlantica and Amphisbaena ridleyi) from Fernando de Noronha archipelago, Brazil. J. Parasitol., 95(4): 1026 - 1028. DOI: 10.1645/GE-1689.1

Recorder, R., Teixeira, M., Camacho, A., Rodrigues, M.T. (2012): Natural history of the tropical gecko Phyllopezus pollicaris (Squamata, Phyllodactylidae) from a sandstone outcrop in Central Brazil. Herpetol. Notes, 5: $49-58$

Ribeiro, S.C., Ferreira, F.S., Brito, S.V., Teles, D.A., Ávila, R.W., Almeida, W.O., Anjos, L.A., Guarnieri, M. (2012): Pulmonary infection in two sympatric lizards, Mabuya arajara (Scincidae) and Anolis brasiliensis (Polychrotidae) from a cloud forest in Chapada do Araripe, Ceará, Northeastern Brazil. Braz. J. Biol., 72(4): 929 933. DOI: 10.1590/S1519-69842012000500021

Rocha, P.L., Rodrigues, M.T. (2005): Electivities and resource use by an assemblage of lizards endemic to the dunes of the São Francisco River, northeastern Brazil. Pap. Avulsos Zool., 45(22): 261 - 284. DOI: 10.1590/S0031-10492005002200001

Sousa, J.G.G., RibeiRo, S.C., Roberto, I.J., Teles, D.A., Almeida, W.O. (2010): Ocorrência de pentastomídeos (Metameria: Ecdysozoa) no lagarto Phyllopezus pollicaris (Spix, 1825) [Occurrence of pentastomides (Metameria: Ecdysozoa) in the lizard Phyllopezus pollicaris 
(Spix, 1825)]. Cad. Cult. Ciênc., 2(2): 64 - 71 (In Portuguese) Sousa, J.G.G., Brito, S.V., Ávila, R.W., Teles, D.A., Araujo-Filho, J.A., Telxeira, A.A. M., Anjos, L.A., Almeida, W.O. (2014): Helminths and Pentastomida of two synanthropic gecko lizards, Hemidactylus mabouia and Phyllopezus pollicaris, in an urban area in Northeastern Brazil. Braz. J. Biol., 74(4): 943 - 948. DOI: 10.1590/1519-6984.01413

Teixeira, A.A.M., Brito, S.V., Teles, D.A., Ribeiro, S.C., Araujo-Filho, J.A., Lima, V.F., Pereira, A.M.A., Almeida, W.O. (2017): Helminths of the Lizard Salvator merianae (Squamata, Teiidae) in the Caatinga, Northeastern Brazil. Braz. J. Biol., 77.2 (2017): 312
- 317. DOI: 10.1590/1519-6984.13515

VRCibradic, D., Rocha, C.F.D., BuRsey, C.R., Vicente, J.J. (2002): Helminth communities of two sympatric skinks (Mabuya agilis and Mabuya macrorhyncha) from two 'restinga' habitats in southeastern Brazil. J. Helminthol., 76(4): 355 - 361. DOI: 10.1079/ JOH2002134

VITT, L.J. (1995): The ecology of tropical lizards in the Caatinga of northeast Brazil. Oklahoma Museum Natl. Hist., 1(1): 1 - 29.

WiLson, K., GrenfelL, B.T. (1997): Generalised linear modelling for parasitologists. Parasitol. Today., 13(1): 33 - 38. DOI: 10.1016/ S0169-4758(96)40009-6 